\title{
Obituary
}

\section{Prof. Godwin Fernando}

M. Fernando ${ }^{1}$, S. Dalpatadu ${ }^{2}$

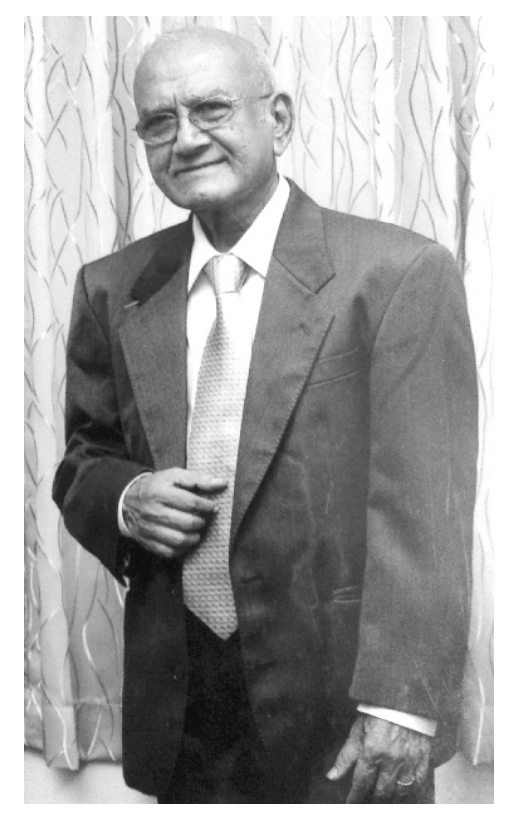

The passing away of Prof.G.P.C (Godwin) Fernando on June $8^{\text {th }} 2014$ after a prolonged illness at the age of $84 \mathrm{yrs}$ brought to an end a long and illustrious career dedicated to the development of public health services of Sri Lanka.

He graduated from the University of Ceylon in 1957. After a brief stint in the curative sector, he opted for a career in public health, where he served tirelessly in different parts of the country. He proceeded to the United Kingdom for his postgraduate training in public health before assuming duties in 1972 as the Chief $\mathrm{MOH}$ Kalutara in charge of the Institute of Hygiene.

Kalutara health unit ( $\mathrm{MOH}$ Kalutara) was the first health unit set up in the South East Asia region. It served a dual purpose of looking after the public health of the population of Kalutara while functioning as the main training center for public health personnel in Ceylon. In 1966 this $\mathrm{MOH}$ unit and the training center was upgraded as the Institute of Hygiene, Kalutara.

\begin{abstract}
As the Chief MOH Kalutara he had to overcome numerous obstacles in providing quality training as his authority was confined to the Institute, while the field practice area was under the MOHs who were answerable to SHS Kalutara. However, the tide turned with the appointment of his colleague Dr.Nelson Jayasuriya as SHS Kalutara and in 1974 the Institute of Hygiene, was decentralized with its own field practice area and became independent of SHS. He was appointed as its first Director. Thereafter he was able get the Ministry to create career posts and to recruit a few dedicated medical officers to the Institute. These officers shouldered the heavy burden of training as well as field work enabling him to concentrate on developing the Institute further.
\end{abstract}

The Regional Director WHO/SEARO at that time was Dr.V.T.Herath Gunaratne. He was keen on developing the Institute of Hygiene, Kalutara into a Regional Public Health Training Centre for South East Asia. In Dr.Godwin Fernando he found the ideal person to implement this project. In 1978 WHO provided financial assistance and technical support through the University of Hawaii and many other organizations to develop the concept of National Institute of Health Sciences (NIHS). Dr.Godwin and his team of medical and paramedical staff worked tirelessly to make this dream a reality. The key factor was the dedication and leadership of Dr.Godwin Fernando, who made many personal sacrifices, including foregoing promotional opportunities to higher administrative positions in the Health Ministry. The culmination of his endeavours was the establishment of the NIHS on $1^{\text {st }}$ July 1979 and his appointment as the first Director of this prestigious institute.. 
After retirement from the Health Department in 1985, he continued his love of teaching by joining the North Colombo Medical College, Ragama (NCMC) as Professor of Community Medicine where he was instrumental in producing a large number of doctors with positive attitudes towards community medicine. The support he received from his family went a long way in helping him face the many challenges encountered during this period.
Being a devout catholic, he was actively involved in the service activities of the St.Luke's Guild of Catholic Doctors.

The number of medical and paramedical personnel he was responsible for training in public health will bear witness to the great service done by him in his own quiet and unassuming way to the public health services of Sri Lanka. 